\section{Earnings Persistence and Market Reaction to Earnings in the International Insurance Industry}

\author{
Persistência e Reação do Mercado aos Resultados Contábeis na Indústria \\ Internacional de Seguros
}

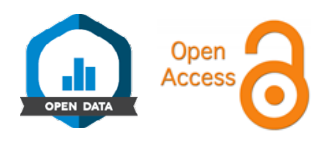

Renê Coppe Pimentel*1

\section{ABSTRACT}

Objective: this paper analyses the earnings persistence and market reaction to earnings in the international insurance industry. Methods: the analysis considers a sample of 307 listed international insurance companies from 2004 to 2019 and assesses several quantitative empirical models and estimations, including panel fixed effects and pooled OLS. Results: results indicate that operating cash flows are highly and strongly persistent when compared to the accruals component of earnings and that reported earnings are informative about companies' performance. However, these findings vary significantly across insurance sub-segments. Additionally, the association between earnings and returns is significantly affected by specific companies' performances in the sense that market agents review their expectation in a higher level when a reduction in earnings (bad news) is reported. Results also show that market risk patterns are positively associated with earnings response coefficient, suggesting a numerator effect of risk. Conclusions: overall, this paper provides evidence that economic analysis and scrutiny of earnings persistence and the market reaction to earnings announcements in insurance industry, and its insurance sub-segments, can provide superior assessment of future outcomes by investors, regulators, and academics.

Keywords: insurance industry; earnings persistence; earnings response coefficient; accounting; market-based accounting.

\footnotetext{
* Corresponding Author.

1. Universidade de São Paulo, Faculdade de Economia, Administração, Contabilidade e Atuária, São Paulo, SP, Brazil.
}

\section{RESUMO}

Objetivo: este artigo analisa a persistência dos lucros contábeis e a reação do mercado a tais resultados na indústria internacional de seguros. Métodos: a análise considera uma amostra de 307 seguradoras internacionais listadas entre 2004 e 2019 e avalia diversos modelos empíricos quantitativos, incluindo efeitos fixos e pooled OLS robustos. Resultados: os resultados indicam que os fluxos de caixa operacionais são mais persistentes em relação ao componente de accruals dos resultados e que os lucros contábeis são informativos sobre a performance das empresas. No entanto, esses resultados variam significantemente entre os subsegmentos da indústria de seguros. Adicionalmente, a relação entre resultados contábeis e retornos de mercado é afetada pelo desempenho específico das empresas, sugerindo que o mercado revisa suas expectativas sobre o desempenho futuro das empresas de forma mais acentuada quando há redução inesperada nos lucros divulgados (notícias ruins), enquanto a revisáo para boas notícias (aumento dos lucros) é menos acentuada. Resultados também mostram que os padróes de risco de mercado indicam associaçáo positiva com o coeficiente de resposta aos lucros, sugerindo um efeito numerador do risco de mercado. No entanto, nenhuma relação significativa foi documentada em relaçáo à parcela dos passivos de seguros e anuidades como proxy de risco setorial específico. Conclusáo: em geral, este artigo fornece evidências de que a análise econômica e o escrutínio da persistência dos lucros e a reaçáo do mercado à divulgaçáo de lucros no mercado segurador, e seus subsegmentos, podem fornecer uma avaliaçáo superior dos resultados futuros por investidores, reguladores e acadêmicos.

Palavras-chave: indústria de seguros; persistência de lucros; coeficiente de resposta de lucros; contabilidade; contabilidade baseada no mercado.

Editors-in-chief: Wesley Mendes-da-Silva (Fundação Getulio Vargas, EAESP, Brazil) (1)
Marcelo de Souza Bispo (Universidade Federal da Paraiba, PPGA, Brazil) (1)
Guest Editors: João Vinícius de França Carvalho (Universidade de São Paulo, FEA, Brazil)
Eduardo Flores (Universidade de São Paulo, FEA, Brazil)
Emiliano A. Valdez (University of Connecticut, USA)




\section{INTRODUCTION}

The market reaction to accounting information is not homogeneous across all firms, industries, countries, and accounting standards. Firm-level heterogeneity plays a significant role in how the market reacts, especially in firms with a greater degree of information asymmetry and operating complexity, such as the insurance industry (Abdallah, Abdallah, \& Salama, 2018). In this regard, Polonchek and Miller (1999) argue that, historically, investors of insurance companies were relatively uninformed, "since the perceived risk of holding insurance company securities was low and the perceived quality of insurance company assets was high" (Polonchek \& Miller, 1999, p. 459). However, these perceptions changed through time, especially after the 90 's and the 2008's subprime financial crisis, since most of the assets and liabilities of insurance companies are measured at the fair value and potentially affected by managers' judgment and subjectivism (Alnodel, 2018), making the accounting process a key element for decision-making by investors and regulators.

Hence, understanding the pattern of accounting earnings and operating cash flows is relevant to forecast future economic outcomes in prudential supervision (Wagner \& Zemp, 2012), to assess the capacity to assume additional risks (Chambers, Freeman, \& Koch, 2005), and to assess the performance drivers of insurance companies (Dechow, Ge, \& Schrand, 2010). Nevertheless, the empirical evidence on accounting information in the insurance industry is scarce, especially when focusing on stock/market valuation and investors, analysts, and portfolio managers' decision. This lack of empirical evidence is especially clear when compared to the evidence on non-financial companies and banks. This paper aims to reduce this gap.

Specifically, this paper empirically analyses the earnings persistence and market reaction to earnings and their determinants in the international insurance industry. The sample is composed by 307 listed international insurance companies from 2004 to 2019 and the analysis is conducted using the insurance industry as a broad economic activity and its sub-segments individually: life and health; multi-line; property and casualty; and reinsurance. The empirical models are well supported by previous literature and fixed-effects and polled OLS procedures are applied to an unbalanced panel with clustered robust standard errors estimation and additional estimation procedures were also conducted and discussed.

Abdallah, Abdallah, and Salama (2018) highlight several aspects to make a cross-country analysis of the insurance industry an interesting and challenging setting to examine earnings properties and investors reaction to accounting information: first, assets and liabilities of insurance firms are opaque, making the evaluation of firms both difficult and costly. Second, since most of insurance firms' assets and liabilities are financial instruments, fair value accounting and its impacts are relevant to investors. Third, insurance accounting varies significantly across jurisdictions, hindering investors' ability to make comparisons across firms, countries, and insurance subindustries. Finally, the operating complexity and inherent risk of insurance firms create information problems between investors and firms (Abdallah et al., 2018).

Hence, due to the unique features of each insurance sub-segment and each regulatory background, the degree of market reaction to accounting information is expected to vary across them. While these differences allow several comparisons among insurance sub-segments and regulatory backgrounds, they increase complexity in the analyses. As a consequence, this paper includes control variables and specific cross-segment analysis. In particular, financial figures and risk of life and non-life insurance companies vary significantly between them (Polonchek \& Miller, 1999) and earnings of non-life insurance firms are more volatile and cannot be readily predicted when compared to life-insurers, compelling investors in non-life insurers to demand higher quality financial reporting to compensate the added risk (Abdallah et al., 2018).

Results indicate that operating cash flows are highly and strongly persistent when compared to the accruals component, and that earnings news is informative about companies' future outcomes and it is significantly affected by specific companies' performances in the sense that market agents review their expectation about future outcomes in a higher level when a reduction (bad news) in earnings is reported, while the result for good news is less strong. Results also show that market risk patterns have positive association with earnings response coefficient, suggesting a numerator effect of risk as discussed by Chambers, Freeman, and Koch (2005). However, no significant relationship was documented regarding the portion of insurance and annuity liabilities as a proxy for risk. Finally, evidence in this paper shows that sub-segments of insurance industry play a key role in accounting persistence and in the market reaction to earnings; hence, segment-specific analysis or specific segment controls should be considered.

Overall, this paper provides evidence that economic analysis and scrutiny of earnings persistence and market reaction to earnings announcements in the insurance industry can provide superior assessment of future outcomes by investors, regulators, and academics, especially if differences in regulation of prudential supervision are taken into consideration. From a regulation point of view, the persistence of earnings and accrual components in insurance companies have direct implications in earnings 
estimation and forecast, understanding the effect of these processes in accounting figures may provide more accurate decisions to regulatory bodies. From a stock market perspective, the dynamic in which investors incorporate accounting information in price can provide more efficient decisions in investment and portfolio allocation, especially in a globally diversified portfolio (Chen, 2013). In an academic context, this paper analysis an industry that have specific characteristics in its operations and accounting procedures that are challenging and, somehow, underexplored in the literature. While this paper provides overall evidence, it also suggests specific paths for future studies and analyses.

The remainder of this paper is organized as follows. The next section reviews the relevant literature and develops the empirical hypothesis. In the sequence, the empirical models and variables are presented and discussed, followed by the presentation and description of general aspects of the sample. Finally, the empirical findings, additional tests, and limitations are presented and discussed, which are followed by final considerations, concluding remarks and suggestions for future research.

\section{LITERATURE REVIEW AND HYPOTHESIS DEVELOPMENT}

\section{Accounting in the insurance industry}

The accounting system applied to insurers is historically based on statutory accounting principles (SAP) primarily for measuring and monitoring solvency (BarNiv, 1990), since the insurance industry is a strongly regulated activity across the world (Harrington, 2009). However, Wagner and Zemp (2012) argue that regulatory framework (solvency and insurance guaranty schemes) and accounting standards need to be considered jointly, due to various interrelations and interactions.

With the adoption of and compliance with International Financial Reporting Standards (IFRS) and local regulation reforms in several countries, the insurance industry underwent substantial changes in financial reporting requirements, leading to a market-oriented valuation of insurance contracts, which may increase the volatility of an insurer's equity position and earnings pattern (Post, Gründl, Schmidl, \& Dorfman, 2007), resulting in a high degree of complexity (Wagner \& Zemp, 2012). At the same time, Ballotta, Esposito, and Haberman (2006) argue that, among other aspects, the fair value procedure applied to insurance contracts enables the identification of an allowance for the default option in the premium, reducing the probability of default for the contract, thereby demonstrating solvency.
In this regard, Ellul, Jotikasthira, Lundblad, and Wang (2014) claim that the role played by fair value accounting was exacerbated during the 2008's financial crisis. This exacerbation compelled many to propose the use of historical cost accounting, promoting its ability to avoid the amplification of systemic risk. However, the authors show that market prices serve as 'early warning signals' to investors and regulators, forcing insurers to be more prudent in their portfolio allocations, while historical cost accounting engaged in greater degrees of regulatory arbitrage and limited loss recognition. Thus, according to the authors, a regulatory simplicity, also in accounting, may be preferred to the complexity of risk-weighted capital ratios.

The bulk of the available literature is fairly (and correctly) based on the accuracy of loss reserves, since this is an important issue for policy makers, stockholders, and regulators and "inaccurate estimates of loss reserves result in the misstatement of liabilities and policyholders' surplus" (Weiss, 1985, p. 199). In this regard, since studies from Anderson (1971) up to recent empirical evidence in Ding, Lev, Peng, Sun, and Vasarhelyi (2020), academics have been investigating the determinants, consequences, and accuracy of insurance-related liabilities and their value relevance to decision-making. Grace (1990), Gaver and Paterson (2004), and Grace and Leverty (2012), among others, show that loss reserves estimates are subject to accounting manipulations, motivated by solvency/regulatory incentives, tax incentives, executive compensation incentives, and income smoothing. Moreover, most of empirical analysis is based on propertycausality insurers, such as Beaver and McNichols (1998; 2001), Beaver, McNichols, and Nelson (2003), Petroni (1992), BarNiv (1990), and Eckles, Halek, He, Sommer, and Zhang (2011). Overall, the literature documented that managers have optimistic estimation of loss reserves (Petroni, 1992); that the recognized loss reserves do not fully reflect available information and that investors partially identify the management of reported loss reserves, and adjust firm values accordingly (Beaver $\&$ McNichols, 1998; 2001); that loss reserve errors are significantly more negative for firms with large positive earnings, suggesting firms with large positive earnings use discretion to lower earnings (Beaver, McNichols, \& Nelson, 2003); and, finally, that managers use discretionary accounting components to affect earnings for compensation enhancement (Eckles, Halek, He, Sommer, \& Zhang, 2011).

Recent evidence in Ding et al. (2020) shows that machine learning can substantially improve managerial estimates of losses. Specifically, the authors document that the loss estimates generated by machine learning are superior to actual managerial estimates reported in financial statements in four out of five insurance lines examined, which have implications to managers, auditors, regulators, and investors due to the material impact of loss estimation on insurance 
firms' financial results. Moreover, since auditors, investors, and regulators are naturally concerned with the quality of the estimates reported by managers, Ding et al. (2020) show that machine learning has the potential to substantially improve auditors' ability to evaluate accounting estimates, thereby enhancing the usefulness of financial information to investors.

In terms of recognition of value relevance of accounting numbers by market agents, Abdallah et al. (2018), by using an event study method, examine the market reaction of the European insurance industry to the adoption of IFRS and document that investors reacted favorably to most of the events that led to the adoption of IFRS, being this favorable reaction especially true for investors of nonlife insurance companies. However, the authors could not conclude whether the benefits of IFRS adoption exceed its costs (i.e., increase audit fees and/or managerial discretion). Similarly, Alnodel (2018) also analyses the value relevance of accounting information for insurance firms and shows that the adoption of IFRS reduces the value relevance of book value of equity and increases the relevance of earnings. The author also documents that the relevance of accounting is influenced by company-specific attributes such as profitability and size.

\section{Earnings persistence and its components}

The earnings persistence coefficient is a key measure of earnings quality and accounting informativeness (Dechow et al., 2010; Kothari, 2001). The financial performance of a firm has permanent and transitory components, where the permanent portion is expected to affect expected future outputs while the transitory portion will not help explain expected future performance as its effects will not persist over time (Easton \& Zmijewski, 1989). In this regard, the residual income valuation (RIV) model (Ohlson, 1995) assumes that firm value is influenced by abnormal earnings; in turn, abnormal earnings follow an autoregressive process in which the parameter of earnings persistence indicates how sensitive the firm value is to earnings realization. As a consequence, earnings persistence is strongly related to earnings forecast and valuation accuracy (Baginski, Lorek, Willinger, \& Branson, 1999; Call, Hewitt, Shevlin, \& Yohn, 2016; Dechow et al., 2010; Pimentel \& Aguiar, 2016).

This paper analyses the role of earnings persistence in the international insurance industry by decomposing earnings persistence on its cash flow and accruals components. Specifically, the literature has documented that the persistence of earnings can be decomposed in terms of cash flows and accruals and these two components may have different persistence. Sloan (1996) shows that operating cash flow is more related with future earnings than accruals since accruals reverse faster than earnings in subsequent periods.
In other words, as earnings components, the accrual portion of earnings is less persistent than operating cash flows. However, the persistence of earnings is determined by the level (magnitude) of accruals, since accruals improve the persistence of earnings relative to cash flows in high accrual firms, but reduce earnings persistence in low accrual firms (Dechow \& Ge, 2006).

The empirical literature confirms these associations between cash and accruals components in non-financial firms under different economic contexts, showing that accruals, regardless of whether they are managed to produce a desired level of earnings or not, are less persistent than the cash flow components (Hui, Nelson, \& Yeung, 2016; Lewellen \& Resutek, 2019; Livnat \& Santicchia, 2006; Pimentel \& Malacrida, 2020). However, as a practical consequence of the higher persistence of the cash component compared to accruals, the economic fundamentals that drive firms' performance and accounting metrics are jointly informative about firms' future earnings (Hui et al., 2016). This leads to the first hypothesis of this paper:

$\mathrm{H} 1$ : As a component of reported earnings, operating cash flows are more persistent than the accruals component.

The study of accruals and cash flows components of earnings is a relevant aspect in insurance companies since they have a higher proportion of financial instruments, and those can suffer variations arising from fair value measures. In this regard, Thesing and Velte (2021) document that the literature of fair value accounting provides mixed results about earnings quality, but in most cases lower-level fair value measurements decrease earnings quality. Moreover, as stated earlier in this paper, the literature has provided strong evidence that estimation of loss reserves is subject to high discretion level by managers (Beaver \& McNichols, 1998; 2001; Beaver et al., 2003; Ding, Lev, Peng, Sun, \& Vasarhelyi, 2020; Petroni, 1992). Hence, putting together the effect of fair value measurement and estimation of loss reserves, the level of discretionary accruals represents most of the performance estimation (earnings) of insurance firms.

\section{Earnings response coefficient and its determinants}

It is well accepted and documented that financial statements provide useful information for market participants (Kothari, 2001). However, the information content and the overall market characteristics have a direct impact on the magnitude by which market agents incorporate new information of accounting numbers in stock prices through time. The long-term dynamic between earnings announcements and stock returns is often measured 
as the linear combination between unexpected earnings and abnormal return (Pimentel \& Lima, 2010) and the general idea is that the higher the magnitudes of ERC and the levels of $\mathrm{R}^{2}$, the higher the informativeness and the usefulness of accounting earnings to investors.

Although the bulk of literature has provided significant evidence on the usefulness of accounting earnings in several industries, in the insurance industry the evidence is limited. Most of empirical evidence is based on non-financial firms. Ariff, Fah, and Ni (2013), for instance, analyze the role or earnings response coefficient in the strongly regulated banking industry and they find that the risk specificity of the industry, such as interest rates and currency exchange rates, strongly affects the way the market reacts to accounting information. In this regard, Hui, Nelson, and Yeung (2016) show that the effect of industry specificity is strongly relevant to define the way market incorporates new information of earnings.

Due to the relevance of specific industry features and the lack or empirical evidence in the insurance industry, the second research hypothesis of this paper is:

$\mathrm{H} 2$ : Earnings response coefficient is positive, indicating that earnings news is informative about companies' future outcomes in the insurance industry.

The literature shows that market agents react differently to good and bad news in accounting earnings (Conrad, Cornell, \& Landsman, 2002; Chen, 2013; Hui et al., 2016). In this regard, it should be of interest to analyze if good (positive earnings changes) and bad (negative earnings changes) news in earnings, proxied by increases and decreases in unexpected earnings, leads to different reactions by market participants. The expectation is conflicting: on the one hand, accounting conservatism studies suggest that market agents react more to positive earnings news, since negative earnings tend to revert faster than positive earnings (Basu, 1997; Hayn, 1995). On the other hand, using earnings response coefficient estimation in the US market, Conrad, Cornell, and Landsman (2002) document that stock prices respond most strongly to bad news in earnings, and this negative response to earnings surprises is increasing as the market level rises, while the results for good news is less strong.

According to Conrad et al. (2002), the higher impact of bad news is explained by to mechanisms: first, investors inappropriately extrapolate past performance and the bad news has the effect of correcting overoptimistic projections. Second, the market will respond more strongly to bad news than good news when stock prices are high. Additionally, Mian and Sankaraguruswamy (2012) show that stock price reaction to earnings news is conditional to investor sentiment sensitivity and market agents react more to bad news in earnings during periods of low sentiment and that mispricing of earnings contributes to the general mispricing of stocks due to investor sentiment. Thus, the third hypothesis suggests that:

H3: Earnings response coefficient is highly affected by decreases in unexpected earning (i.e., bad news).

As documented by Ariff et al. (2013) and Hui et al. (2016), industry specific risks affect the earnings response coefficient. Moreover, market and firm-specific risk are key determinants of market reaction to earnings. Chambers et al. (2005), using the standard valuation model, show a duality in the risk effect by documenting and providing explanations to numerator and denominator effects of risk on earnings response coefficient. The authors show that earnings response coefficient may increase with total risk because the sensitivity of dividend expectations to firmspecific news is an increasing function of risk.

H4: Earnings response coefficient is positively associated with firm-specific risk.

Additionally, Ball, Kothari, and Watts (1993) suggest that the presence of corporate debt makes the analysis of economic determinants of earnings response coefficient less clear since leverage seems to affect the relationship between changes in investment risk and unexpected earnings. In this regard, this paper includes a market-based measure of risk (beta) and an insurance-specific measure to relate the insurance liability component to total assets.

In all hypotheses, there are different estimations for the entire insurance industry and each sub-segment, since Abdallah et al. (2018) find that investors' reaction to IFRS adoption differs between insurance segments. Specifically, they document that investors in the non-life insurance industry react more favorably to IFRS adoption, which indicates that they anticipate that the benefits of IFRS will exceed the costs.

\section{EMPIRICAL DESIGN AND VARIABLES DESCRIPTIONS}

\section{Earnings persistence and determinants of earnings processes}

According to Dichev and Tang (2009) and Frankel and Litov (2009), earnings persistence can be described as the first-order autocorrelation of annual reported earnings deflated by total assets at the end of period $t$.

$X_{t i}=\alpha+\beta X_{t-1 i}+\varepsilon_{i t}$ 
where $X$ is the annual reported earnings before extra items and preferred dividends at year $t$ divided by total assets at the end of period $t$ and $\beta$ is the proxy for earnings persistence. In the spirit of financial statement analysis and valuation, Clubb and Wu (2014) consider reported earnings as 'core earnings' and assume that all components of earnings have the same persistence. This premise assumes that reported earnings are the effective measure of fundamental financial performance (see Dechow et al., 2010) and, thus, accruals and cash flow have the similar persistence.

However, as suggested and documented by Sloan (1996), Hui et al. (2016), and Livnat and Santicchia (2006), earnings persistence can be decomposed in two components related to cash flows and accruals. Specifically, they show that cash flow components are more closely associated with future earnings than accruals since accruals reverse faster than earnings in subsequent periods. Thus, the Equation 1 is decomposed to accommodate both components:

$X_{i t}=\Omega_{0}+\Omega_{1} X C F_{i t-1}+\Omega_{2} X A C C_{i t-1}+v_{i}+\varepsilon_{i t}$

where $X C F_{i t-1}$ is the operating cash flow portion in earnings of the company $i$ at year $t-1$, and XACCit-1 is the total accrual portion, defined as reported net income less operating cash flows (i.e., XACCit=Xit-XCFit) and $v_{i}$ is the firm-specific fixed effect. According to previous empirical evidence, it is expected that $\Omega_{1}>\Omega_{2}$.

The accruals processes have practical importance since they significantly affect future earnings and operating cash flow estimations, by increasing or reducing the accuracy of future performance forecasts by market agents. The autoregressive parameters in Equation 2 are estimated and presented under the cluster-robust fixed-effect panel framework and assume linearity of estimated coefficients under time series assumptions. However, additional estimation processes are conducted including pooled ordinary least squares (OLS), generalized linear models (GLM), random effect generalized linear models (GLM), and generalized estimating equation (GEE) populationaveraged model. The choice of the presenting model is based on diagnostic statical tests and is discussed in the empirical results.

\section{Earnings response coefficient and risk}

The baseline model to estimate the earnings response coefficient, fairly explored in the empirical literature, is:

$U R_{i t}=\lambda_{0}+\lambda_{1} U X_{i t}+\varepsilon_{i t}$

where $\lambda_{1}$ is the earnings response coefficient that relates cumulated unexpected return $U R_{i t}$ with unexpected earnings (the new information in earnings) for company $i$ at year $t$ and $\varepsilon_{i t}$ is the error term. In this paper, the basic model is extended to account for specific characteristics related to the time components, sub-segment of insurance industry, geographical region (country), and accounting standard:

$U R_{i t}=\lambda_{0}+\lambda_{1} U X_{i t}+\sum d y e a r+\sum d s u b i n d+\sum d c o u n t+\sum d g a a p+\varepsilon_{i t}$

where:

$U R_{i t}=$ unexpected returns for firm $i$ cumulated over year $t$, where UR is accumulated excess return adjusted for firm-specific risk and conditional to the realized market return for period t. The excess return is calculated by the difference between observed return $\left(R_{i}\right)$ and the expected return based on market portfolio return $\left(R_{m}\right)$ and adjusted for the systematic risk component (beta). Market portfolio return $\left(R_{m}\right)$ is the weighed stock return of the companies in the sample (the MSCI World Insurance Index was also used as a market portfolio proxy and the results are qualitatively the same, although the MSCI index is a significantly more restricted sample than the sample used in this paper). Consistent with previous studies, the annual returns are cumulated from April of year $t$ to March of $t+1$ to capture any return reaction associated with the announcement of earnings for year $t$.

$U X_{i t}=$ unexpected earnings for firm $i$ in the year $t$, where $U X$ is the nominal variation of reported earnings, $X$, in year $t$ (fiscal year) scaled by the market value of equity (MVE) in the beginning of the period. Thus, $U X_{i t}=\left(X_{i t}-X_{i t-1}\right) / M V E_{i t-1}$, where the implicit assumption is that earnings follow a random walk process, which assumes that the current period's annual earnings are the best unbiased expectation of the next period's earnings (Ariff, Fah, \& Ni, 2013).

dyear = set of dummy variables to control for each year in the analysis.

dsubind = set of dummy variables to control for each subsegments in the insurance industry.

dcount = set of dummy variables to control for each country.

dgaap = set of dummy variables to control for each accounting standard.

The literature shows that market agents react differently to good and bad news in accounting earnings (Chen, 2013; Conrad et al., 2002; Hui et al., 2016; Mian \& Sankaraguruswamy, 2012). In this regard, Equation 4 was split in to good and bad news in earnings, proxied by increases and decreases in unexpected earnings. The 
underling idea is that market agents react differently for positive and negative earnings news. In addition to the sample split, a dummy variable decrearn, assuming one for decreasing in unexpected earnings and zero otherwise, was interacted with the unexpected earnings, aiming to confirm any potential significant relationship. Hence:

$$
U R_{i t}=\lambda_{0}+\lambda_{1} U X_{i t}+\lambda_{2} U X_{i t} * \text { decrearn }_{i t}+\lambda_{3} \text { decrearn }_{i t}+\sum d y e a r+\sum d \text { subind }+\sum d c o u n t+\sum d g a a p+\varepsilon_{i t}
$$

where $\lambda_{2}$ is expected to be positive if market agents react more for bad news (i.e., decreasing in unexpected earnings) as suggested and documented by Conrad et al. (2002).
Finally, an extended version of Equation 5 was implemented in order to consider market and companyspecific risk, earnings persistence, and nonlinear effects of earnings as follows:

$$
\begin{gathered}
U R_{i t}=\rho_{0}+\rho_{1} U X_{i t}+\rho_{2} U X_{i t} * P E R_{i}+\rho_{3} U X * N L E F_{i t}+\rho_{4} U X_{i t} * S R I S K_{i}+\rho_{5} U X * I N S L I A B_{i t}+\rho_{6} P_{E R}+\rho_{7} N L E F_{i t}+ \\
\rho_{8} \text { SRISK }_{i}+\rho_{9} I_{N S L I A B_{i t}}+\sum d \text { year }+\sum d \text { count }+\sum \text { gaap }+\sum d \text { subind }+\varepsilon_{i t}
\end{gathered}
$$

where:

$P E R_{i}=$ is the firm-specific earnings persistence as the autoregressive coefficient, $\beta$, in Equation 1 estimated during the period of analysis.

$N L E F_{i t}=$ is measured as the ranked absolute value of scaled earningsdefinedas: $n l e f=\left(|X| \operatorname{Rank}_{i t}-1\right) /(N-1)$ , where $|X|$ Rank $_{i t}$ is the rank of the absolute value of deflated earnings of firm $i$ at year $t$ with $N$ being the number of observations in a given year.

$\operatorname{SRISK}_{i}=$ is the firm-specific measure of systematic risk, based on market model beta, where market portfolio return $\left(R_{m}\right)$ is the weighted stock return of the companies in the sample.

$I N S L I A B_{i t}=$ is the amount of insurance and annuity liabilities of company $i$ at year $t$ deflated by total assets.

The parameters in Equations 3 to 6 are estimated and presented under the cluster-robust pooled OLS framework and assume linearity of estimated coefficients. However, additional estimation processes are conducted including panel fixed and random effects, generalized linear models (GLMs), and generalized estimating equation (GEE) population-averaged model.

The option for presentation of OLS estimates is based on diagnostic statistics of poolability F-test, Hausman, and Breusch-Pagan tests and it is discussed in the empirical results. Specifically, according to the poolability F-test (presented at the lower part of each table), the hypothesis that the observed and unobserved fixed effects, $u_{i}$, are equal to zero could not be rejected (fixed effects are equal across units). While fixed effects provide controls for all firmspecific time-invariant aspects, the pooled OLS estimations presented in this paper control for several aspects related to the environment in which insurance companies are inserted (i.e., country, accounting GAAP, and sub-segments of insurance industry). Additionally, Freeman, Koch, and Li (2011) document that "ERCs from firm-specific regressions provide less accurate predictions of price responses to future earnings surprises than ERCs from pooled regressions" (Freeman, Koch, \& Li, 2011, p. 35). All equations were implemented considering standard errors with robust estimation by correcting for diagonal heteroscedasticity (White, 1980). Following Chen (2013), Frankel and Litov (2009), and others, for brevity and length restriction, the coefficient estimates of the factors' main effects (i.e., the intercepts for interacted term component) are not reported.

All empirical data was collected in the S\&P Capital IQ international database from 2004 to 2019 forming an unbalanced sample. The number of observations may vary according to the availability of specific variables in the analysis. For instance, the study relating market variables is subjective to market in a specific period. When applicable, variables were winsorized at $1 \%$ level in order to reduce the bias derived from extreme outliers. The variables were collected and analyses were conducted considering the following sub-segments of insurance industry: property and casualty, life and health, multi-line and reinsurance, as described in detail in the next section.

\section{SAMPLE DEFINITION AND DESCRIPTION}

The sample is composed of public companies classified in the insurance industry in the G20 countries, including all European countries, with minimum financial and market information available at the S\&P Capital IQ international database. 
The sample construction started by selecting all 75,316 insurance industry companies available at the database. From those, 851 public companies were selected. The country criteria, which include all G20 countries plus all European countries, reduced the sample to 485 insurance companies classified in (a) property and casualty insurance; (b) life and health insurance; (c) multi-line insurance; (d) reinsurance; and (e) insurance brokers. Due to the commercial and service provider nature of the insurance brokers subsector, the 74 insurance brokers companies were excluded from the sample. Additionally, 104 companies did not present financial data from more than three consecutive years, which made them ineligible.

Hence, the final sample is composed of an unbalanced panel of 307 insurance companies classified as follows: 115 property and casualty insurance; 95 multi-line insurance; 83 life and health insurance; 14 reinsurance. Yearly financial and market data was collected from 2004 to 2019. The use of public (listed) companies is fundamental to the research problem, since it demand market price information, which is not available for private firms. Indeed, it is important to highlight that most of insurance companies are not listed and most of them are included in financial conglomerates, what makes impossible to analyze specific market reaction to insurance activities and restrict the sample of analysis.

Table 1 shows the composition and description of the sample with key financial and market figures in 2019, the last year available to time series' length. Panel A of Table 1 describes the sample according to the insurance segment (sub-industries) and shows that the life and health segment is the one with larger companies, in terms of market capitalization and financials, followed by multi-line insurance, property and casualty, and reinsurance. However, the segment property and casualty is the one with the larger number of firms. Overall, the sample covers USD 2.4 trillion in market capitalization with a total managed asset of USD 23.9 trillion in 2019 .

Overall, from the total asset held by the companies, $9.4 \%$ is financed by equity instruments, being the property and casualty segment the less leveraged, on average. At the same time, the life and health segment is the one with more cash and short-term investments held by companies on average (11.9\%), while multi-line insurance and reinsurance are the segments with lower cash and short-term investment liquidity, on average.

In terms of insurance and annuity liabilities relevance, the multi-line insurance is the segment with the highest portion of assets compromised by these insurance-specific liabilities $(50.1 \%)$, on average. Property and casualty is the segment with lower liabilities to total assets $(31.2 \%)$, on average.

Panel B of Table 1 shows key financial and market figures in 2019 of the top ten total (aggregation of) market capitalization of companies according to the countries where the companies' headquarter is located and their shares primary listed. Obviously, one (multinational) company can operate in several markets; however, all information collected is based on consolidated operations in the holding company. USA, China, and Switzerland are the top three countries in terms of market capitalization.

Although the values are presented in country-specific aggregate terms, it is important to highlight the difference in capital structure and asset composition among the countries. For instance, Hong Kong (61.6\%) and Germany (60.9\%) are the countries (or territory/market in the case of Hong Kong) with the highest portion of assets compromised by insurance and annuity liabilities; however, Hong Kong is the market with the largest portion of cash and short-term investments $(24.3 \%)$, while Germany is the lowest (5.2\%).

Table 1. Sample composition and description.

\begin{tabular}{|c|c|c|c|c|c|c|c|c|c|c|c|}
\hline \multicolumn{12}{|c|}{ Panel A - Sample and financial information in 2019 by sub-segment segregation (in billions of US dollars) } \\
\hline Segment & $\begin{array}{c}\text { No. of } \\
\text { compa- } \\
\text { nies }\end{array}$ & $\begin{array}{l}\text { Market } \\
\text { capital- } \\
\text { ization }\end{array}$ & $\begin{array}{l}\text { Total } \\
\text { assets }\end{array}$ & $\begin{array}{l}\text { Total } \\
\text { equity }\end{array}$ & $\begin{array}{l}\% \text { of } \\
\text { total } \\
\text { assets }\end{array}$ & $\begin{array}{l}\text { Cash \& ST } \\
\text { investments }\end{array}$ & $\begin{array}{c}\% \text { of } \\
\text { Total } \\
\text { assets }\end{array}$ & $\begin{array}{l}\text { Insurance } \\
\& \text { annuity } \\
\text { liabilities }\end{array}$ & $\begin{array}{l}\% \text { of } \\
\text { total } \\
\text { assets }\end{array}$ & $\begin{array}{c}\text { Net } \\
\text { income }\end{array}$ & $\begin{array}{l}\text { Cash flows } \\
\text { from op- } \\
\text { erations }\end{array}$ \\
\hline Life and health insurance & 83 & $1,113.3$ & 15,090.9 & $1,100.4$ & $7.3 \%$ & $1,798.0$ & $11.9 \%$ & $5,969.6$ & $39.6 \%$ & 92.4 & 216.4 \\
\hline Multi-line insurance & 95 & 631.0 & $5,869.6$ & 580.3 & $9.9 \%$ & 294.9 & $5.0 \%$ & $2,942.9$ & $50.1 \%$ & 52.4 & 122.0 \\
\hline $\begin{array}{l}\text { Property and casualty } \\
\text { insurance }\end{array}$ & 115 & 579.9 & $2,126.0$ & 446.5 & $21.0 \%$ & 157.4 & $7.4 \%$ & 663.1 & $31.2 \%$ & 47.4 & 60.7 \\
\hline Reinsurance & 14 & 144.7 & 872.8 & 124.0 & $14.2 \%$ & 37.4 & $4.3 \%$ & 298.8 & $34.2 \%$ & 9.0 & 24.7 \\
\hline Overall total & 307 & $2,468.9$ & $23,959.3$ & $2,251.2$ & $9.4 \%$ & $2,287.6$ & $9.5 \%$ & $9,874.5$ & $41.2 \%$ & 201.2 & 423.8 \\
\hline
\end{tabular}


Table 1. Sample composition and description (continued).

\begin{tabular}{|c|c|c|c|c|c|c|c|c|c|c|c|}
\hline \multicolumn{12}{|c|}{ Panel B - Sample and financial information in 2019 by country (in billions of US dollars) } \\
\hline Country & $\begin{array}{l}\text { Nr. of } \\
\text { Compa- } \\
\text { nies }\end{array}$ & $\begin{array}{l}\text { Market } \\
\text { Capital- } \\
\text { ization }\end{array}$ & $\begin{array}{l}\text { Total } \\
\text { assets }\end{array}$ & $\begin{array}{l}\text { Total } \\
\text { equity }\end{array}$ & $\begin{array}{l}\% \text { of } \\
\text { total } \\
\text { assets }\end{array}$ & $\begin{array}{l}\text { Cash \& ST } \\
\text { Investments }\end{array}$ & $\begin{array}{l}\% \text { of } \\
\text { total } \\
\text { assets }\end{array}$ & $\begin{array}{l}\text { Insurance } \\
\& \text { annuity } \\
\text { liabilities }\end{array}$ & $\begin{array}{l}\% \text { of } \\
\text { total } \\
\text { assets }\end{array}$ & $\begin{array}{c}\text { Net } \\
\text { income }\end{array}$ & $\begin{array}{c}\text { Cash flows } \\
\text { from oper- } \\
\text { ations }\end{array}$ \\
\hline United States & 91 & 567.0 & $4,510.6$ & 557.0 & $12.3 \%$ & 151.6 & $3.4 \%$ & $1,881.3$ & $41.7 \%$ & 51.0 & 94.5 \\
\hline China & 10 & 487.3 & $2,410.4$ & 304.5 & $12.6 \%$ & 269.7 & $11.2 \%$ & $1,122.7$ & $46.6 \%$ & 43.4 & 106.4 \\
\hline Switzerland & 8 & 196.4 & $1,217.1$ & 155.7 & $12.8 \%$ & 115.9 & $9.5 \%$ & 465.9 & $38.3 \%$ & 12.0 & 19.0 \\
\hline Germany & 7 & 182.7 & $1,860.7$ & 159.1 & $8.6 \%$ & 96.4 & $5.2 \%$ & $1,133.0$ & $60.9 \%$ & 14.8 & 63.7 \\
\hline Japan & 9 & 148.5 & $4,610.5$ & 298.9 & $6.5 \%$ & 734.3 & $15.9 \%$ & $1,529.6$ & $33.2 \%$ & 14.9 & 0.1 \\
\hline Canada & 11 & 138.1 & $1,739.8$ & 140.7 & $8.1 \%$ & 264.2 & $15.2 \%$ & 701.7 & $40.3 \%$ & 12.7 & 30.5 \\
\hline Hong Kong & 4 & 136.9 & 412.1 & 72.1 & $17.5 \%$ & 100.3 & $24.3 \%$ & 253.8 & $61.6 \%$ & 7.8 & 17.1 \\
\hline United Kingdom & 15 & 133.7 & $2,238.7$ & 82.6 & $3.7 \%$ & 116.1 & $5.2 \%$ & 872.8 & $39.0 \%$ & 8.8 & 0.5 \\
\hline France & 4 & 91.1 & $1,431.4$ & 126.5 & $8.8 \%$ & 138.8 & $9.7 \%$ & 467.3 & $32.6 \%$ & 6.6 & 21.2 \\
\hline Italy & 7 & 60.8 & $1,054.8$ & 64.4 & $6.1 \%$ & 32.0 & $3.0 \%$ & 459.3 & $43.5 \%$ & 6.3 & 27.1 \\
\hline 33 other countries & 141 & 326.4 & $2,473.2$ & 289.7 & $11.7 \%$ & 268.3 & $10.8 \%$ & 987.1 & $39.9 \%$ & 23.0 & 43.9 \\
\hline Overall total & 307 & $2,468.9$ & $23,959.3$ & $2,251.2$ & $9.4 \%$ & $2,287.6$ & $9.5 \%$ & $9,874.5$ & $41.2 \%$ & 201.2 & 423.8 \\
\hline
\end{tabular}

Note. In order to allow proper comparison, all market and financial values are converted to US dollars with exchange rate at the end of the year 2019.

\section{EMPIRICAL RESULTS}

\section{Earnings persistence and determinants of earnings processes}

The first broad objective of this study is to estimate and analyze earnings persistence and its components. In this regard, Table 2 displays the decomposition of cash flow and accruals components of earnings in order to analyze the information content of each component, according to Equation 2, and confirms expectation that both operating cash flow and accruals are positively associated with earnings and that operating cash flows are highly and strongly persistent compared to the accruals component. Thus, this evidence is consistent with previous empirical literature, since accruals revert in the short term (Dechow \& Ge, 2006; Lewellen \& Resutek, 2019; Sloan, 1996).

The results displayed in Table 2 also provide an interesting comparison with previous literature: on the one hand, Dichev and Tang (2009), Frankel and Litov (2009), and Clubb and Wu (2014) document that increases in earnings volatility are strongly associated with reductions of earnings persistence, implying that accounting earnings timely incorporate economic reality. On the other hand, Polonchek and Miller (1999) document that earnings of non-life insurance firms are more volatile and cannot be readily predicted when compared to their life-insures peers. Analyzing Table 2, it is possible to note that the life and health segment has high nominal persistence coefficients of operating cash and accruals components compared to other non-life segments, suggesting that it is also the less volatile segment.

Additionally, the results displayed in Table 2 are consistent across the entire sample and two segments of the insurance industry, property and casualty and multiline insurance; in the life and health and reinsurance, however, the persistence coefficients of cash flows and accruals are not statistically different between then. That is, accruals are less persistent than cash flows as a component of reported earnings. According to Lewellen and Resutek (2019), there are three possible explanations to the low persistence of accruals. First, subjectivity and distortions in financial statements lead to transitory measurement error in accruals and earnings. The second explanation suggests that accruals are closely linked to investment activities leading to decreasing returns to scale and/or increasing costs associated with investment. The third explanation is based on the way firms' profits and working capital respond to demand and supply shocks in product markets.

Results presented in Table 2 are estimated using panel fixed-effect approach, since the poolability F-test (presented at the lower part of the table) rejects the hypothesis that the observed and unobserved fixed effects, $u_{i}$, are equal to zero (fixed effects are equal across units). In order to test for potential correlations between the error component $u_{i}$ and regressors, the Hausman test was performed and the results, displayed in the lower part of Table $2\left(\chi^{2}=293.97\right)$, indicate the rejection of the null hypothesis that estimators under fixed and random effect are identical. As discussed in limitations and additional tests section, alternative estimation approaches were performed, and the results of Table 2 remain strongly supported. 
Table 2. Decomposition of earnings persistence: cash flow vs. accruals components (Equation 2).

\begin{tabular}{|c|c|c|c|c|c|c|c|c|c|c|}
\hline \multirow[b]{2}{*}{ Const. $\left(\Omega_{0}\right)$} & \multicolumn{2}{|c|}{ Full sample } & \multicolumn{2}{|c|}{$\begin{array}{c}\text { Property and casualty } \\
\text { insurance }\end{array}$} & \multicolumn{2}{|c|}{ Multi-line insurance } & \multicolumn{2}{|c|}{$\begin{array}{l}\text { Life and health } \\
\text { insurance }\end{array}$} & \multicolumn{2}{|c|}{ Reinsurance } \\
\hline & 0.009 & *** & 0.015 & $* * *$ & 0.006 & $* * *$ & 0.005 & $* * *$ & 0.013 & $* * *$ \\
\hline & $(14.52)$ & & (11.23) & & $(7.11)$ & & $(5.87)$ & & $(12.00)$ & \\
\hline \multirow[t]{2}{*}{$X C F_{t-1}\left(\Omega_{1}\right)$} & 0.277 & $* * *$ & 0.249 & $* * *$ & 0.288 & $* * *$ & 0.315 & $* * *$ & 0.229 & $* * *$ \\
\hline & $(9.05)$ & & $(5.46)$ & & $(5.72)$ & & $(5.17)$ & & $(3.88)$ & \\
\hline \multirow[t]{2}{*}{$X A C C_{t-1}\left(\Omega_{2}\right)$} & 0.188 & $* * *$ & 0.162 & $* * *$ & 0.169 & $* * *$ & 0.272 & $* * *$ & 0.261 & $* * *$ \\
\hline & $(6.48)$ & & $(3.37)$ & & $(3.81)$ & & $(4.75)$ & & $(6.30)$ & \\
\hline $\begin{array}{l}F \text {-test of coefficient equality } \\
(X C F=X A C C)\end{array}$ & 16.79 & $* * *$ & 6.060 & $*$ & 10.00 & $* *$ & 1.500 & & 0.300 & \\
\hline Observations & 3,472 & & 1,286 & & 1,120 & & 889 & & 177 & \\
\hline $\mathrm{R}^{2}$ & 0.363 & & 0.328 & & 0.298 & & 0.510 & & 0.547 & \\
\hline F-test & 40.95 & $* * *$ & 15.19 & $* * *$ & 16.36 & $* * *$ & 13.77 & $* * *$ & 21.30 & $* * *$ \\
\hline F-Chow (poolability) & 3.78 & $* * *$ & 4.19 & $* * *$ & 2.69 & $* * *$ & 4.15 & $* * *$ & 6.39 & $* * *$ \\
\hline Hausman test & 293.97 & $* * *$ & 42.52 & $* * *$ & 155.43 & $* * *$ & 357.99 & $* * *$ & 93.20 & $* * *$ \\
\hline Breusch-Pagan test & 86.44 & $* * *$ & 49.91 & $* * *$ & 10.45 & $* * *$ & 0.00 & & 0.00 & \\
\hline
\end{tabular}

Note. Dependent variable, $X$, is defined as reported annual net income deflated by total assets. $X C F_{t-1}$ and $X A C C_{t-1}$ are lagged operating cash flow and accruals deflated by total assets, respectively. $X A C C_{i t-1}$ is the total accrual portion, defined as reported net income less operating cash flows (i.e., $X A C C_{i t}=X_{i t}-X C F_{i t}$ ). According to previous empirical evidence, it is expected that $\Omega_{1}>\Omega_{2}$. Estimation based on fixed-effect panel with robust estimation. $t$-statistics are in parentheses. ${ }^{* * *},{ }^{* *}$, and ${ }^{*}$ indicate correlations statistically significant at $1 \%, 5 \%$, and $10 \%$ levels, respectively.

Additionally, estimation of firm-specific autoregressive parameter was performed in the operating cash flows and accruals components and the results (not displayed) show that from the 307 insurance firms in the sample, 195 (63.5\%) have higher persistence of cash flows component than accruals, supporting the findings in Table 2.

Overall, the results documented in this section confirm expectation that both operating cash flow and accruals are positively associated with earnings and that operating cash flows are highly and strongly persistent compared to the accruals component. However, these results are not constant across all insurance sub-segment, suggesting that the industry sub-segments and operating activities are relevant to explain earnings patterns. Specifically, life and health segment has high nominal persistence coefficients compared to other non-life segments, suggesting that it is also the less volatile segment and confirming the findings of Polonchek and Miller (1999). Hence, economic analysis and scrutiny of these characteristics can provide superior assessment of future outcomes by investors, regulators, and academics. While this paper offers a set of well-documented determinants of earnings persistence, additional research avenues can be explored in order to fully understand the mechanisms by which accounting information can provide useful information in the insurance industry and the decision-making process in general.

\section{Earnings response coefficient}

The second broad objective of this paper is to estimate and analyze market reaction to earnings innovation. In this regard, Table 3 displays the basic earnings response coefficient parameter in Equation 4 and the earnings response coefficient conditional to company performance (where good and bad news are proxied by expansions or reductions in reported earning, respectively).

The results in this section are presented under pooled OLS approach since the poolability F-test, presented at the lower part of Tables 3 and 4, indicates that, under standard significance level, it is not possible to reject the hypothesis that the observed and unobserved fixed effects, $u_{i}$, are equal to zero (fixed effects are equal across units). As discussed earlier, while fixed effects provide controls for all firmspecific time-invariant aspects, the pooled OLS estimations presented in this paper control for several aspects related to the environment in which insurance companies are inserted (i.e., time, country, accounting GAAP, and sub-segments of insurance industry). As discussed in limitations and additional tests section, alternative estimation approaches were performed and discussed.

Similar to previous analyses, estimations were conducted considering the entire sample and the four segments of insurance industry. As expected, Panel A of 
Table 3 shows that all annual earnings response coefficients are positive and significant, showing that the release of reported accounting earnings provided useful (new) information to market participants (Kothari, 2001). This is consistent across the entire sample and all insurance segments.

Although the magnitudes of coefficients are not directly comparable due to differences in sample size, nominally, market seems to react more for earnings announcements in the reinsurance industry and less in the multiline insurance, when the segments are compared.

Panel B of Table 3 shows that the market reacts differently to new information derived from increases (good news) and reductions (bad news) in earnings. Firstly, the sample is split in two fractions, the response to an increase in earnings and to a decrease in earnings, and secondly the baseline model is interacted with a dummy variable indicating decreases in earnings. The results show that market agents review their expectation about future outcomes in a higher level when a reduction (bad news) in earnings is documented. This result is consistent with the empirical findings provided by Conrad et al. (2002), who document that market agents respond most strongly to bad news in earnings, while the result for good news is less strong, and the results documented by Mian and Sankaraguruswamy (2012), who show that stock price sensitivity to bad earnings news is higher during periods of low sentiment. Additionally, this evidence can corroborate the findings of Chen (2013), who shows that market agents do not fully recognize the earnings process in their firm-value assessment.

Table 3. Earnings response coefficient - baseline model and performance decomposition.

\begin{tabular}{|c|c|c|c|c|c|c|c|c|c|c|c|c|}
\hline \multicolumn{13}{|c|}{ Panel A - Baseline model of earnings response coefficient (Equation 4) } \\
\hline & \multicolumn{2}{|c|}{ Full sample } & \multicolumn{2}{|c|}{$\begin{array}{c}\text { Property and casualty } \\
\text { insurance }\end{array}$} & \multicolumn{2}{|c|}{ Multi-line insurance } & \multicolumn{3}{|c|}{$\begin{array}{l}\text { Life and health } \\
\text { insurance }\end{array}$} & \multicolumn{3}{|c|}{ Reinsurance } \\
\hline \multirow[t]{2}{*}{ Const. } & 0.005 & & -0.013 & & 0.039 & & & & & & -0.003 & \\
\hline & $(0.06)$ & & $(-0.12)$ & & $(0.47)$ & & & & & & $(-0.02)$ & \\
\hline \multirow[t]{2}{*}{$U X$} & 0.693 & $* * *$ & 0.732 & $* * *$ & 0.531 & $* * *$ & & & $* * *$ & & 1.945 & $* * *$ \\
\hline & $(6.95)$ & & $(5.07)$ & & $(2.7)$ & & & & & & $(7.21)$ & \\
\hline Year controls & yes & & yes & & yes & & & & & & yes & \\
\hline $\begin{array}{l}\text { Country/region } \\
\text { controls }\end{array}$ & yes & & yes & & yes & & & & & & yes & \\
\hline GAAP controls & yes & & yes & & yes & & & & & & yes & \\
\hline Sub-industry controls & \multicolumn{2}{|l|}{ yes } & & & & & & & & & & \\
\hline Observations & \multicolumn{2}{|l|}{3,021} & \multicolumn{2}{|l|}{1,145} & \multicolumn{2}{|l|}{914} & \multicolumn{3}{|c|}{806} & \multicolumn{3}{|c|}{156} \\
\hline $\mathrm{R}^{2}$ & \multicolumn{2}{|l|}{0.107} & \multicolumn{2}{|l|}{0.123} & \multicolumn{2}{|l|}{0.117} & \multicolumn{3}{|c|}{0.147} & \multicolumn{3}{|c|}{0.370} \\
\hline $\mathrm{F}$ & \multicolumn{2}{|l|}{5.89} & \multicolumn{2}{|l|}{22.63} & \multicolumn{2}{|c|}{$4.22^{* * *}$} & \multicolumn{3}{|c|}{3.54} & \multicolumn{3}{|c|}{$4.28^{* * *}$} \\
\hline F-Chow & \multicolumn{2}{|l|}{0.90} & \multicolumn{2}{|l|}{0.86} & \multicolumn{2}{|l|}{0.86} & \multicolumn{3}{|c|}{1.09} & \multicolumn{3}{|c|}{1.08} \\
\hline Hausman & \multicolumn{2}{|l|}{12.68} & 9.39 & & 5.46 & & & & & & 13.57 & \\
\hline Breusch-Pagan & 0.00 & & 0.00 & & 0.00 & & & & & & 0.00 & \\
\hline & Panel & $\mathrm{B}-\mathrm{E}$ & s response c & oefficient ac & according to ea & rnings perf & ce ( & 1a & ation 5) & & & \\
\hline & Positi & ve unex & earnings (g & ood & Negative unexp & $\begin{array}{l}\text { ected earni } \\
\text { hews) }\end{array}$ & & & Entire sar & nple - i & integrativ & ve dummy \\
\hline Const. & & & & & 0.04 & & & & & 0.071 & $* * *$ & \\
\hline & & & & & $(0.83$ & & & & & $(2.70)$ & & \\
\hline$U X$ & & & & & 0.93 & $6^{* * *}$ & & & & 0.391 & $* * *$ & \\
\hline & & & & & $(5.13$ & & & & & $(2.69)$ & & \\
\hline$U X^{*}$ decrearn & & & & & & & & & & 0.550 & ** & \\
\hline & & & & & & & & & & $(2.40)$ & & \\
\hline decrearn & & & & & & & & & & -0.051 & $* * *$ & \\
\hline & & & & & & & & & & $(3.06)$ & & \\
\hline
\end{tabular}


Table 3. Earnings response coefficient — baseline model and performance decomposition (continued).

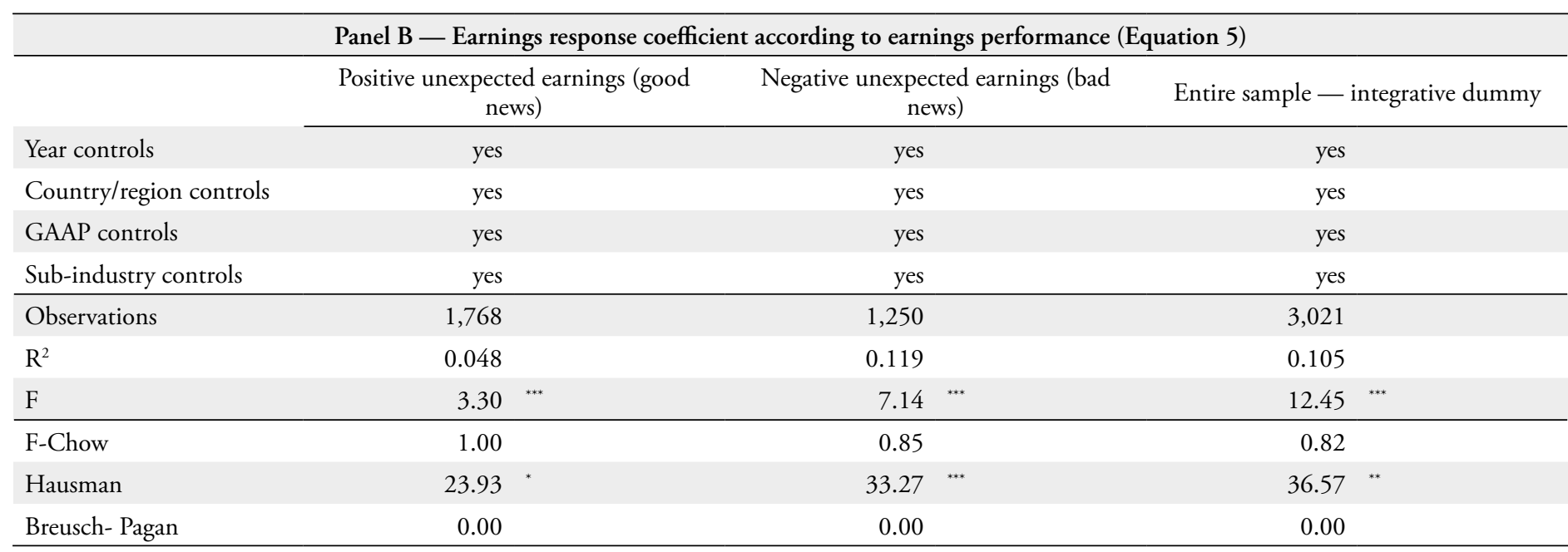

Note. Dependent variable, $U R_{i t}$, is the unexpected returns for firm $i$ cumulated over year $t$, where $U R$ is accumulated excess return adjusted for firm-specific risk and conditional to the realized market return for period $t . U X_{i t}$ is the unexpected earnings for firm $i$ in the year $t$, where $U X$ is the nominal variation of reported earnings, $X$, in year $t$ (fiscal year) scaled by the market value of equity in the beginning of the period. decrearn is a dummy variable assuming one when unexpected earnings decrease in relation to $t-1$ and zero otherwise. OLS robust $t$-statistics with White (1980) corrections are in parentheses. ${ }^{* *},{ }^{* *}$, and ${ }^{*}$ indicate correlations statistically significant at $1 \%, 5 \%$, and $10 \%$ levels, respectively.

Table 4 shows the extended model of earnings response coefficient with control for persistence of earnings and risk factors. The results for the entire sample suggest that the earnings response coefficient varies inversely with nonlinear effect of earnings and varies positively with firm-specific systematic risk. No significant relationship was documented with firm-specific earnings persistence and insurance-specific liabilities.

The results shed some light on relevant aspects related to the variations in the way the market reacts to earnings in the international insurance market. Although the literature has provided strong evidence of positive association between earnings response coefficient and earnings persistence, this relationship is not documented in the international insurance market under de sample, period, and empirical implementation described in this paper. However, the interactive term of NLEF is confirmed to be negatively associated with the earnings response coefficient, since a higher absolute value of $U X$ tends to decrease the magnitude of the response coefficient (Freeman \& Tse, 1992). Specifically, this evidence suggests that extreme earnings variations are interpreted by market agents as a transitory element of earnings, that is, an extreme increase (or decrease) in earnings does not imply an extreme revision in earnings price and future expectations.
The results also show that the earnings response coefficient is affected by companies' and market risk patterns in a positive association, suggesting a numerator effect of risk as discussed by Chambers et al. (2005). Specifically, Chambers et al. (2005) show that the earnings response coefficient increases with firm-specific systematic risk because the sensitivity of dividend expectations to firmspecific news is an increasing function of risk. However, no significant relationship was documented regarding the portion of insurance and annuity liabilities as a proxy for risk. This evidence does not confirm the expectation based on Ball et al. (1993), who suggest that the presence of corporate liabilities makes the analysis of economic determinants of earnings response coefficient less clear since leverage seems to affect the relationship between changes in investment risk and unexpected earnings. Moreover, this evidence suggests, under de sample, period, and empirical implementation described in this paper, that the level of insurance liability does not affect the way market prices incorporate the news provided by accounting earnings. This evidence, however, does not suggest that insurance liability information is not recognized by the market, but, instead, suggests that there is no impact on the market recognition of accounting earnings innovation (news). In any case, the evidence provided in this paper may inspire new investigations in this subject, which is actually neglected by the literature in terms of international insurance market. 
Table 4. Earnings response coefficient — extended model for risk (Equation 6).

\begin{tabular}{|c|c|c|c|c|c|c|c|c|c|c|c|}
\hline \multirow[b]{2}{*}{ Const. $\left(\rho_{0}\right)$} & \multicolumn{2}{|c|}{ Full sample } & \multicolumn{2}{|c|}{$\begin{array}{c}\text { Property and casualty } \\
\text { insurance }\end{array}$} & \multicolumn{2}{|c|}{ Multi-line insurance } & \multicolumn{2}{|c|}{$\begin{array}{c}\text { Life and health } \\
\text { insurance }\end{array}$} & \multicolumn{3}{|c|}{ Reinsurance } \\
\hline & 0.055 & & -0.071 & & 0.168 & $*$ & 0.147 & & & 0.128 & \\
\hline & $(0.62)$ & & $(-0.39)$ & & $(1.77)$ & & $(1.52)$ & & & $(0.48)$ & \\
\hline \multirow[t]{2}{*}{$\mathrm{UX}\left(\rho_{1}\right)$} & 0.631 & ** & 0.878 & ** & 0.249 & & 0.795 & & & -0.804 & \\
\hline & (2.18) & & $(1.95)$ & & $(0.51)$ & & $(1.35)$ & & & $(-0.43)$ & \\
\hline \multirow[t]{2}{*}{$U X^{*} \operatorname{PER}\left(\rho_{2}\right)$} & -0.215 & & -2.077 & $* * *$ & 0.916 & & 0.010 & & & 3.2 & \\
\hline & $(-0.68)$ & & $(-2.86)$ & & $(1.35)$ & & $(0.04)$ & & & $(1.27)$ & \\
\hline \multirow[t]{2}{*}{$U X^{*} N L E F\left(\rho_{3}\right)$} & -0.759 & $* * *$ & -0.479 & & -1.144 & $* *$ & -0.201 & & & -0.758 & \\
\hline & $(-2.91)$ & & $(-1.41)$ & & $(-2.48)$ & & $(-0.38)$ & & & $(-0.71)$ & \\
\hline \multirow[t]{2}{*}{$U X^{*} \operatorname{SRISK}\left(\rho_{4}\right)$} & 0.314 & ** & 0.410 & $* * *$ & 0.754 & $* * *$ & -0.472 & & * & 5.457 & $* * *$ \\
\hline & $(2.38)$ & & $(2.97)$ & & $(2.97)$ & & $(-1.68)$ & & & $(2.59)$ & \\
\hline \multirow[t]{2}{*}{$U X^{*} \operatorname{INSLIAB}\left(\rho_{5}\right)$} & -0.031 & & -0.623 & & 0.209 & & 0.568 & & & -2.445 & $* *$ \\
\hline & $(-0.08)$ & & $(-1.07)$ & & $(0.34)$ & & $(0.83)$ & & & $(-2.02)$ & \\
\hline Year controls & yes & & yes & & yes & & yes & & & yes & \\
\hline Country/region controls & yes & & yes & & yes & & yes & & & yes & \\
\hline GAAP controls & yes & & yes & & yes & & yes & & & yes & \\
\hline Sub-industry controls & yes & & & & & & & & & & \\
\hline Observations & 2,561 & & 828 & & 836 & & 753 & & & 144 & \\
\hline $\mathrm{R}^{2}$ & 0.120 & & 0.158 & & 0.177 & & 0.172 & & & 0.146 & \\
\hline $\mathrm{F}$ & 6.41 & $* * *$ & 90.64 & $* * *$ & 5.01 & $* * *$ & 3.57 & $* * *$ & & 1.76 & $* *$ \\
\hline F-Chow (poolability) & 0.76 & & 0.79 & & 0.74 & & 1.16 & & & 0.73 & \\
\hline Hausman test & 32.54 & * & 19.89 & & 14.57 & & 28.54 & & & 0.02 & \\
\hline Breusch-Pagan test & 0.00 & & 0.00 & & 0.00 & & 0.00 & & & 0.00 & \\
\hline
\end{tabular}

Note. Dependent variable, $U R_{i t}$, is the unexpected returns for firm $i$ cumulated over year $t$, where $U R$ is accumulated excess return adjusted for firm-specific risk and conditional to the realized market return for period $t . U X_{i t}$ is the unexpected earnings for firm $i$ in the year $t$, where $U X$ is the nominal variation of reported earnings, $X$, in year $t$ (fiscal year) scaled by the market value of equity in the beginning of the period. $P E R_{i t}$ is the firm-specific earnings persistence, the $\beta$ coefficient in Equation 1 estimated over the period of analysis. $N L E F_{i t}$ is measured as the ranked absolute value of scaled earnings defined as: $n l e f=\left(|X| R_{a n k}-1\right) /(N-1)$. SRISK is the firm-specific measure of systematic risk, based on market model beta, where market portfolio return $\left(R_{m}\right)$ is the weighted stock return of the companies in the sample. INSLIAB is the amount of insurance and annuity liabilities of company $i$ at year $t$ deflated by total assets. Interaction terms are all presented, but their intercepts (non-interacted terms) are omitted for the sake of space. F-chow poolability, Hausman, and Breush-Pagan tests are presented in the lower part of the table. OLS robust $t$-statistics with White (1980) corrections are in parentheses. Only interaction terms are presented, while non-interacted terms are omitted. ${ }^{* * *},{ }^{* *}$, and ${ }^{*}$ indicate correlations statistically significant at $1 \%, 5 \%$, and $10 \%$ levels, respectively.

The results in Table 4 differ across sub-segments of insurance industry, being the model less significant and consistent in multi-line, life and health, and reinsurance segments. These variations across segments are consistent with the segment differential market reaction documented by Abdallah et al. (2018). Specifically, there may be additional and different determinants of the earnings response coefficient, suggesting new avenues for further research in the international insurance industry field. Moreover, similar to Abdallah et al. (2018), results in Table 4 suggest that investors in property and casualty insurance segments react more favorably to accounting information. Maybe, as indicated in the review of the literature, it may be an explanation for the high number of accounting studies in this segment.
Overall, the results show that the earnings response coefficient is positive and statistically significant across the entire sample and each of the sub-segments of insurance industry, indicating that earnings news is informative about companies' future outcomes ( $\mathrm{H} 2$ ). Additionally, earnings response coefficient is significantly affected by specific companies' performance in terms of good (unexpected earnings increases) and bad (unexpected earnings decreases) news. Specifically, reductions in earnings (bad news) are associated with a higher response to earnings news (H3). Finally, results show that the earnings response coefficient is affected by the risk patterns of companies and the market in a positive association (H4), suggesting a numerator effect of risk as discussed by Chambers et al. (2005). However, no significant relationship was documented regarding the 
portion of insurance and annuity liabilities as a proxy for risk.

\section{LIMITATIONS, EMPIRICAL CONCERNS, AND ADDITIONAL TESTS}

\section{Sample representativeness, data adequacy, and variables accuracy}

The research design is subject to a series of assumptions and choices from researchers and the results may be affected by these choices. In this regard, the sample analyzed in this paper is based on public companies classified in the insurance industry in the G20 countries available at the S\&P Capital IQ international database. As explained, this sample does not comprise all insurance institutions, since market prices are a requirement to the study and, thus, restriction to listed companies is necessary. However, this choice excludes large insurance companies that may be privately held or may be included in a larger financial conglomerate, which is a common practice in several markets analyzed. Hence, the sample is representative only for listed insurance companies with headquarters in G20 country.

The analysis is based on archival research and relies on the outputs from the S\&P Capital IQ international database. Due to the differences in economic and regulation environment in a cross-country analysis, the standardization of accounts and currencies may affect the total comparability of firms and accounting practices. Estimation approaches were chosen in order to reduce the impact of these differences; however, the impacts may only be mitigated, but not totally eliminated.

Finally, the variables constructions are strongly based on previous literature. However, the results may change due to different choices in variable measurement. These effects of error measurement in the variables are often indicated in the literature as a way of conflicting empirical results. For instance, earnings persistence can be measured under different time series assumptions (Baginski et al., 1999; Kothari, 2001).

As the analysis of accounting information in insurance industry is still scarce in the literature, this paper may provide a starting point for additional empirical analysis, as indicated along previous sections of this paper.

\section{Estimation concerns}

As mentioned in previous sections, the earnings persistence and earnings response coefficient analyses are based on the well-accepted models in the literature and motivate the presentations of the results above. However, at the same time, the literature is not unanimous in defining an estimation approach and a time series model that represent earnings in all conditions and environments (Kothari, 2001).

In this regard, alternative estimations were conducted using pooled ordinary least squares (OLS), panel fixed and random effect models, generalized linear models (GLM), and generalized estimating equation (GEE) population-averaged model. The estimation approaches used in this paper follow well-accepted estimation procedures in accounting field.

All estimation considered cluster robust estimation with correction for heteroskedasticity and the choice of presenting results was based on diagnostic statical tests as discussed earlier in this paper. Specifically, for the earnings response coefficient analyses, the poolability F-test could not reject the hypothesis that the observed and unobserved fixed effects, $u_{i}$, are equal to zero (fixed effects are equal across units). In order to face this issue, all the pooled OLS estimation control for insurance companies' characteristics, which include year, country, GAAP, and sub-segments of insurance industry dummies variables.

Overall, the results, although quantitatively different, do not invalidate the main conclusions in this paper and, in some cases, present more significant and stable coefficients across insurance segments than the results displayed along this paper. In order to clarify the subject, Table 5 provides simplified comparison of the main models and coefficients estimated.

Finally, by following Hui et al. (2016), this paper also analyzed the intriguing differential effect of industry and firm-specific variables in earnings persistence and the earnings response coefficient. The results (not reported) strongly indicate that firm-specific components of earnings are more relevant than the industry effect. This evidence is expected due to the dispersion of insurance companies and regulation across countries. However, the evidence also shows that it is not possible to determine an 'international insurance market' that represents a common benchmark performance to individual companies. This evidence also represents a limitation in this paper. 
Table 5. Comparison of alternative estimation approaches (simplified presentation).

\begin{tabular}{|c|c|c|c|c|c|c|c|c|c|c|}
\hline \multicolumn{11}{|c|}{ Panel A - Persistence decomposition on operating cash and accruals components (Equation 2) } \\
\hline & \multicolumn{2}{|c|}{ Pooled OLS } & \multicolumn{2}{|c|}{$\begin{array}{c}\text { Fixed effects (displayed } \\
\text { model) }\end{array}$} & \multicolumn{2}{|c|}{ Random effects } & \multicolumn{2}{|c|}{$\begin{array}{l}\text { Generalized linear } \\
\text { models }\end{array}$} & \multicolumn{2}{|c|}{$\begin{array}{l}\text { GEE population - } \\
\text { aver. model }\end{array}$} \\
\hline \multirow[t]{2}{*}{ Const. } & 0.005 & $* * *$ & 0.009 & $* * *$ & 0.007 & $* * *$ & 0.005 & $* * *$ & 0.007 & $* * *$ \\
\hline & $(5.58)$ & & $(14.52)$ & & $(4.98)$ & & $(5.09)$ & & $(5.06)$ & \\
\hline \multirow[t]{2}{*}{$X C F_{t-1}$} & 0.548 & $* * *$ & 0.277 & $* * *$ & 0.385 & $* * *$ & 0.548 & $* * *$ & 0.421 & $* * *$ \\
\hline & $(16.67)$ & & $(9.05)$ & & $(11.26)$ & & $(16.25)$ & & $(12.07)$ & \\
\hline \multirow[t]{2}{*}{$X A C C_{t-1}$} & 0.424 & $* *$ & 0.188 & $* * *$ & 0.278 & $* * *$ & 0.424 & $* * *$ & 0.310 & $* * *$ \\
\hline & $(12.47)$ & & $(6.48)$ & & $(8.16)$ & & $(12.01)$ & & $(8.80)$ & \\
\hline $\begin{array}{l}\text { F-test of Coefficient Equality } \\
(X C F=X A C C)\end{array}$ & 48.95 & $* * *$ & 16.790 & $* * *$ & 25.64 & $* * *$ & 35.320 & $* * *$ & 28.300 & $* * *$ \\
\hline \multicolumn{11}{|c|}{ Panel B — Basic earnings response coefficient model and earnings news (Equation 5) } \\
\hline & \multicolumn{2}{|c|}{$\begin{array}{c}\text { Pooled OLS } \\
\text { (displayed model) }\end{array}$} & \multicolumn{2}{|c|}{ Fixed effects } & \multicolumn{2}{|c|}{ Random effects } & \multicolumn{2}{|c|}{$\begin{array}{c}\text { Generalized linear } \\
\text { models }\end{array}$} & \multicolumn{2}{|c|}{$\begin{array}{l}\text { GEE population - } \\
\text { aver. model }\end{array}$} \\
\hline \multirow[t]{2}{*}{ Const. } & 0.101 & & 0.099 & $* * *$ & 0.101 & ** & 0.101 & $* *$ & 0.098 & $* *$ \\
\hline & $(1.40)$ & & $(2.58)$ & & $(2.07)$ & & $(2.09)$ & & $(2.18)$ & \\
\hline \multirow[t]{2}{*}{$U X$} & 0.374 & $* * *$ & 0.584 & $* * *$ & 0.374 & $* * *$ & 0.374 & $* * *$ & 0.278 & * \\
\hline & $(2.56)$ & & $(3.59)$ & & $(2.41)$ & & $(2.42)$ & & $(1.78)$ & \\
\hline \multirow[t]{2}{*}{$U X^{*}$ decrearn } & 0.571 & $* * *$ & 0.024 & & 0.571 & $* * *$ & 0.571 & $* * *$ & 0.825 & $* * *$ \\
\hline & $(2.47)$ & & $(0.11)$ & & $(3.41)$ & & $(3.43)$ & & $(5.51)$ & \\
\hline \multirow[t]{2}{*}{ decrearn } & -0.05 & $* * *$ & -0.05 & $* * *$ & -0.05 & $* * *$ & -0.05 & $* * *$ & -0.05 & $* * *$ \\
\hline & $(-2.99)$ & & $(-2.56)$ & & $(-2.86)$ & & $(-2.88)$ & & $(-2.91)$ & \\
\hline \multicolumn{11}{|c|}{ Panel C - Earnings response coefficient, earnings properties, and risk (Equation 6) } \\
\hline & \multicolumn{2}{|c|}{$\begin{array}{c}\text { Pooled OLS } \\
\text { (displayed model) }\end{array}$} & \multicolumn{2}{|c|}{ Fixed effects } & \multicolumn{2}{|c|}{ Random effects } & \multicolumn{2}{|c|}{$\begin{array}{c}\text { Generalized linear } \\
\text { models }\end{array}$} & \multicolumn{2}{|c|}{$\begin{array}{c}\text { GEE population } \\
\text { aver. model }\end{array}$} \\
\hline \multirow[t]{2}{*}{ Const. } & 0.055 & & -0.004 & & 0.055 & & 0.055 & & 0.070 & \\
\hline & $(0.62)$ & & $(-0.06)$ & & $(0.73)$ & & $(0.74)$ & & $(1.17)$ & \\
\hline \multirow[t]{2}{*}{$U X$} & 0.631 & ${ }^{* *}$ & 0.225 & & 0.631 & ** & 0.631 & $* *$ & 0.807 & $* * *$ \\
\hline & $(2.18)$ & & $(0.73)$ & & $(2.17)$ & & $(2.19)$ & & $(3.05)$ & \\
\hline$U X^{*} P E R$ & -0.215 & & -0.229 & & -0.215 & & -0.215 & & -0.2 & \\
\hline & $(-0.68)$ & & $(-0.58)$ & & $(-0.62)$ & & $(-0.62)$ & & $(-0.60)$ & \\
\hline$U X^{*} N L E F$ & -0.759 & $* * *$ & -0.243 & & -0.759 & $* * *$ & -0.759 & $* * *$ & -1.048 & $* * *$ \\
\hline & $(-2.91)$ & & $(-1.05)$ & & $(-4.17)$ & & $(-4.21)$ & & $(-6.39)$ & \\
\hline$U X^{*}$ SRISK & 0.314 & ${ }^{* *}$ & 0.335 & $* *$ & 0.314 & $* *$ & 0.314 & ** & 0.341 & $* *$ \\
\hline & $(2.38)$ & & $(2.00)$ & & $(2.11)$ & & $(2.13)$ & & $(2.17)$ & \\
\hline$U X^{*} I N S L I A B$ & -0.031 & & 0.083 & & -0.031 & & -0.031 & & -0.049 & \\
\hline & $(-0.08)$ & & $(0.18)$ & & $(-0.07)$ & & $(-0.07)$ & & $(-0.11)$ & \\
\hline
\end{tabular}

Note. Simplified presentation of coefficient estimates of Equations 2, 5, and 6 under different estimation approaches. Variables were defined earlier and all estimation account for cluster robust estimation with correction for heteroscedasticity. ${ }^{* *},{ }^{* *}$, and ${ }^{*}$ indicate correlations statistically significant at $1 \%, 5 \%$, and $10 \%$ levels, respectively.

\section{CONCLUSION}

This paper analyzes the earnings persistence and market reaction to earnings in the international insurance industry. Specifically, by using a sample of 307 listed international insurance companies from 2004 to 2019, this paper estimates and analyzes earnings persistence and the earnings response coefficient and their determinants. The analysis was conducted using the insurance industry as a broad economic activity and its sub-segments individually. 
Overall, results indicate that both operating cash flow and accruals are positively associated with earnings; however, operating cash flows are highly and strongly persistent when compared to the accruals component $(\mathrm{H} 1)$.

In terms of market reaction to earnings, the results show that the earnings response coefficient is positive and statistically significant across the entire sample and each of the sub-segments of insurance industry, indicating that earnings news is informative about companies' future outcomes $(\mathrm{H} 2)$. Additionally, earnings persistence is significantly affected by specific companies' performances (H3). Specifically, reductions in unexpected earnings (bad news) are associated with a higher response to earnings news when compared to increases in unexpected earnings (good news). Finally, results show that the earnings response coefficient is affected by the risk patterns of companies and the market in a positive association ( $\mathrm{H} 4)$, suggesting a numerator effect

\section{REFERENCES}

Abdallah, A. A.-N., Abdallah, W., \& Salama, F. M. (2018). The market reaction to the adoption of IFRS in the European insurance industry. The Geneva Papers on Risk and Insurance - Issues and Practice, 43(4), 653-703. https://doi.org/10.1057/s41288-018-0088-1

Alnodel, A. A. (2018). The impact of IFRS adoption on the value relevance of accounting information: Evidence from the insurance sector. International Journal of Business and Management, 13(4), 138-148. https://doi.org/10.5539/ijbm.v13n4p138

Anderson, D. R. (1971). Effects of under and overevaluations in loss reserves. Journal of Risk and Insurance, 38(4), 585600. https://doi.org/10.2307/251572

Ariff, M., Fah, C. F., \& Ni, S. W. (2013). Earnings response coefficients of OECD banks: Tests extended to include bank risk factors. Advances in Accounting, 29(1), 97-107. https://doi.org/10.1016/j.adiac.2013.03.003

Baginski, S. P., Lorek, K. S., Willinger, G. L., \& Branson, B. C. (1999). The relationship between economic characteristics and alternative annual earnings persistence measures. The Accounting Review, 74(1), 105-120. https://doi.org/10.2308/accr.1999.74.1.105

Ball, R., Kothari, S., \& Watts, R. L. (1993). Economic determinants of the relation between earnings changes and stock returns. Accounting Review, 68(3), 622-638. Retrieved from https://www.jstor.org/stable/248205 of risk as discussed by Chambers et al. (2005). However, no significant relationship was documented regarding the portion of insurance and annuity liabilities as a proxy for risk.

The paper shows evidence that could potentially contribute to the literature and professional activities. The conflicting in-sample evidence suggests that further research in this field can provide incremental useful evidence to analysts and regulators, especially if differences in regulation of prudential supervision are taken into consideration.

While this paper offers a set of well-documented determinants of earnings persistence and earnings response coefficients, additional research avenues can be explored in order to fully understand the mechanisms by which accounting information can provide useful information about the insurance industry and the decision-making process in general.

Ballotta, L., Esposito, G., \& Haberman, S. (2006). The IASB insurance project for life insurance contracts: Impact on reserving methods and solvency requirements. Insurance: Mathematics and Economics, 39(3), 356-375. https://doi.org/10.1016/j.insmatheco.2006.04.004

BarNiv, R. (1990). Accounting procedures, market data, cashflow figures, and insolvency classification: The case of the insurance industry. The Accounting Review, 65(3), 578604. Retrieved from https://www.jstor.org/stable/247951

Basu, S. (1997). The conservatism principle and the asymmetric timeliness of earnings. Journal of Accounting and Economics, 24(1), 3-37. https://doi.org/10.1016/S0165-4101(97)00014-1

Beaver, W. H., \& McNichols, M. F. (1998). The characteristics and valuation of loss reserves of property casualty insurers. Review of Accounting Studies, 3(1), 73-95. https://doi.org/10.1023/A:1009676300318

Beaver, W. H., \& M. F. McNichols. (2001). Do stock prices of property casualty insurers fully reflect information about earnings, accruals, cash flows and development? Review of Accounting Studies, 6(2-3), 197-220. https://doi.org/10.1023/A:1011662825164

Beaver, W. H., McNichols, M. F., \& Nelson, K. K. (2003). Management of the loss reserve accrual and the distribution of earnings in the property-casualty insurance industry. Journal of Accounting and Economics, 35(3), $347-$ 376. https://doi.org/10.1016/S0165-4101(03)00037-5 
Call, A. C., Hewitt, M., Shevlin, T., \& Yohn, T. L. (2016). Firm-specific estimates of differential persistence and their incremental usefulness for forecasting and valuation. The Accounting Review, 91(3), 811-833. https://doi.org/10.2308/accr-51233

Chambers, D. J., Freeman, R. N., \& Koch, A. S. (2005). The effect of risk on price responses to unexpected earnings. Journal of Accounting, Auditing \& Finance, 20(4), 461-482. https://doi.org/10.1177/0148558X0502000408

Chen, C. (2013). Time-varying earnings persistence and the delayed stock return reaction to earnings announcements. Contemporary Accounting Research, 30(2), 549-578. https://doi.org/10.1111/j.1911-3846.2012.01165.x

Clubb, C., \& Wu, G. (2014). Earnings volatility and earnings prediction: Analysis and UK evidence. Journal of Business Finance \& Accounting, 41(1-2), 53-72. https://doi.org/10.1111/jbfa.12055

Conrad, J., Cornell, B., \& Landsman, W. R. (2002). When is bad news really bad news? The Journal of Finance, 57(6), 2507 2532. https://doi.org/10.1111/1540-6261.00504

Dechow, P. M., \& Ge, W. (2006). The persistence of earnings and cash flows and the role of special items: Implications for the accrual anomaly. Review of Accounting Studies, 11(2), 253-296. https://doi.org/10.1007/s11142-006-9004-1

Dechow, P., Ge, W., \& Schrand, C. (2010). Understanding earnings quality: A review of the proxies, their determinants and their consequences. JournalofAccountingandEconomics, 50(2-3), 344-401. https://doi.org/10.1016/j.jacceco.2010.09.001

Dichev, I. D., \& Tang, V. W. (2009). Earnings volatility and earnings predictability. Journal of Accounting and Economics, 47(1-2), 160-181. https://doi.org/10.1016/j.jacceco.2008.09.005

Ding, K., Lev, B., Peng, X., Sun, T., \& Vasarhelyi, M. A. (2020). Machine learning improves accounting estimates: Evidence from insurance payments. Review of Accounting Studies, 25, 1098-1134. https://doi.org/10.1007/s11142-020-09546-9

Easton, P. D., \& Zmijewski, M. E. (1989). Crosssectional variation in the stock market response to accounting earnings announcements. Journal of Accounting and Economics, 11(2-3), 117-141. https://doi.org/10.1016/0165-4101(89)90003-7

Eckles, D. L., Halek, M., He, E., Sommer, D. W., \& Zhang, R. (2011). Earnings smoothing, executive compensation, and corporate governance: Evidence from the property-liability insurance industry. JournalofRisk and Insurance, 78(3), 761790. https://doi.org/10.1111/j.1539-6975.2011.01417.x

Ellul, A., Jotikasthira, C., Lundblad, C. T., \& Wang, Y. (2014). Mark-to-market accounting and systemic risk: Evidence from the insurance industry. Economic Policy, 29(78), 297341. https://doi.org/10.1111/1468-0327.12030

Frankel, R., \& Litov, L. (2009). Earnings persistence. Journal of Accounting and Economics, 47(1-2), 182-190. https://doi.org/10.1016/j.jacceco.2008.11.008
Freeman, R. N., \& Tse, S. Y. (1992). A nonlinear model of security price responses to unexpected earnings. Journal of Accounting Research, 30(2), 185-209. https://doi.org/10.2307/2491123

Freeman, R. N., Koch, A., \& Li, H. (2011). Can historical returnsearnings relations predict price responses to earnings news? Review of Quantitative Finance and Accounting, 37(1), 3562. https://doi.org/10.1007/s11156-010-0194-z

Gaver, J. J., \& Paterson, J. S. (2004). Do insurers manipulate loss reserves to mask solvency problems? Journal of Accounting and Economics, 37(3), 393-416. https://doi.org/10.1016/j.jacceco.2003.10.010

Grace, E. V. (1990). Property-liability insurer reserve errors: A theoretical and empirical analysis. The Journal of Risk and Insurance, 57(1), 28-46. https://doi.org/10.2307/252923

Grace, M. F., \& Leverty, J. T. (2012). Property-liability insurer reserve error: Motive, manipulation, or mistake. Journal of Risk and Insurance, 79(2), 351-380. https://doi.org/10.1111/j.1539-6975.2011.01434.x

Harrington, S. E. (2009). The financial crisis, systemic risk, and the future of insurance regulation. Journal of Risk and Insurance, 76(4), 785-819. https://doi.org/10.1111/j.1539-6975.2009.01330.x

Hayn, C. (1995). The information content of losses. Journal of Accounting and Economics, 20(2), 125-153. https://doi.org/10.1016/0165-4101(95)00397-2

Hui, K. W., Nelson, K. K., \& Yeung, P. E. (2016). On the persistence and pricing of industry-wide and firmspecific earnings, cash flows, and accruals. Journal of Accounting and Economics, 61(1), 185-202. https://doi.org/10.1016/j.jacceco.2015.06.003

Kothari, S. P. (2001). Capital markets research in accounting. Journal of Accounting and Economics, 31(1-3), 105-231. https://doi.org/10.1016/S0165-4101(01)00030-1

Lewellen, J., \& Resutek, R. J. (2019). Why do accruals predict earnings? Journal of Accounting and Economics, 67(2-3), 336-356. https://doi.org/10.1016/j.jacceco.2018.12.003

Livnat, J., \& Santicchia, M. (2006). Cash flows, accruals, and future returns. Financial Analysts Journal, 62(4), 48-61. https://doi.org/10.2469/faj.v62.n4.4186

Mian, G. M., \& Sankaraguruswamy, S. (2012). Investor sentiment and stock market response to earnings news. The Accounting Review, 87(4), 1357-1384. https://doi.org/10.2308/accr-50158

Ohlson, J. A. (1995). Earnings, book values, and dividends in equity valuation. Contemporary Accounting Research, 11(2), 661-687. https://doi.org/10.1111/j.1911-3846.1995.tb00461.x

Petroni, K. R. (1992). Optimistic reporting in the property-casualty insurance industry. Journal of Accounting and Economics, 15(4), 485-508. https://doi.org/10.1016/0165$\underline{4101(92) 90003-K}$ 
Pimentel, R. C., \& Lima, I. S. (2010). Is the annual earnings response coefficient statitically significant in Brazil. Latin American Business Review, 11(3), 267-291. https://doi.org/10.1080/10978526.2010.513273

Pimentel, R. C., \& Aguiar, A. B. (2016). The role of earnings persistence in valuation accuracy and the time horizon. Revista de Administração de Empresas, 56(1), 71-86. https://doi.org/10.1590/S0034-759020160107

Pimentel, R. C., \& Malacrida, M. J. C. (2020). Quarterly earnings, operating cash flow, and accruals in future performance assessment. Brazilian Administration Review, 17(4), e190115. Retrieved from https://bar.anpad.org.br/index.php/bar/article/view/504

Polonchek, J., \& Miller, R. K. (1999). Contagion effects in the insurance industry. The Journal of Risk and Insurance, 66(3), 459-475. https://doi.org/10.2307/253556

Post, T., Gründl, H., Schmidl, L., \& Dorfman, M. S. (2007). Implications of IFRS for the European insurance industry-insights from capital market theory. Risk Management and Insurance Review, 10(2), 247-265. https://doi.org/10.1111/j.1540-6296.2007.00117.x

\section{Authorship}

\section{Renê Coppe Pimentel*}

Universidade de São Paulo, Faculdade de Economia, Administração, Contabilidade e Atuária

Av. Prof. Luciano Gualberto, n. 908, Butantã, 05508-010, São

Paulo, SP, Brazil

E-mail address: renecp@usp.br

(1) https://orcid.org/0000-0002-8845-049X

* Corresponding Author

\section{Conflict of Interests}

The author have stated that there is no conflict of interest.

\section{Funding}

The author reported that there is no financial support for the research in this article.

\section{Copyrights}

RAC owns the copyright to this content.

\section{Peer Review Method}

This content was evaluated using the double-blind peer review process. The disclosure of the reviewers' information on the first page, as well as the Peer Review Report, is made only after concluding the evaluation process, and with the voluntary consent of the respective reviewers and authors.
Sloan, R. G. (1996). Do stock prices fully reflect information in accruals and cash flows about future earnings? The Accounting Review, 71(3), 289-315. Retrieved from https://www.jstor.org/stable/248290

Thesing, J., \& Velte, P. (2021). Do fair value measurements affect accounting-based earnings quality? A literature review with a focus on corporate governance as moderator. Journal of Business Economics, 91, 965-1004. https://doi.org/10.1007/s11573-020-01025-6

Wagner, J., \& Zemp, A. (2012). Comparison of stakeholder perspectives on current regulatory and reporting reforms. Risk Management and Insurance Review, 15(2), 225-254. https://doi.org/10.1111/j.1540-6296.2012.01218.x

Weiss, M. (1985). A multivariate analysis of loss reserving estimates in property-liability insurers. The Journal of Risk and Insurance, 52(2), 199-221. https://doi.org/10.2307/252512

White, H. (1980). A heteroskedasticity-consistent covariance matrix estimator and a direct test for heteroskedasticity. Econometrica, 48(4), 817-838. https://doi.org/10.2307/1912934

\section{Author's Contributions}

$1^{\text {st }}$ author: conceptualization (lead); data curation (lead); formal analysis (lead); investigation (lead); methodology (lead); project administration (lead); resources (lead); software (lead); supervision (lead); validation (lead); visualization (lead); writing - original draft (lead); writing - review \& editing (lead).

\section{Plagiarism Check}

The RAC maintains the practice of submitting all documents approved for publication to the plagiarism check, using specific tools, e.g.: iThenticate.

\section{Data Availability}

The author claim that all data and materials have been made publicly available through the Harvard Dataverse platform and can be accessed at:

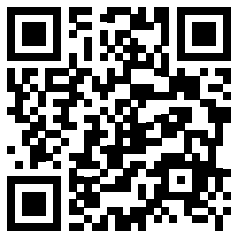

Pimentel, Renê Coppe, 2021, "Replication Data for: "Earnings persistence and market reaction to earnings in the international insurance industry"published by RAC. Revista de Administração Contemporânea", Harvard Dataverse, V1. https://doi.org/10.7910/DVN/JLZH2Z

RAC encourages data sharing but, in compliance with ethical principles, it does not demand the disclosure of any means of identifying research subjects, preserving the privacy of research subjects. The practice of open data is to enable the reproducibility of results, and to ensure the unrestricted transparency of the results of the published research, without requiring the identity of research subjects. 